\title{
Andrzej Wicher*
}

iD https://orcid.org/0000-0001-8568-2087

\section{A comparison between the concept of Newspeak in George Orwell's Nineteen Eighty-Four: A Novel and the way of thinking about language in C.S. Lewis's That Hideous Strength}

The aim of this article is to study some of the possible inspirations which enabled George Orwell to create in Nineteen Eighty-Four: A Novel the concept of Newspeak. However, I am not arguing that such inspirations must have existed. I shall stress the relationships between Orwell's novel and the fantasy novel by C.S. Lewis written a few years earlier as they seem rather striking, though also in this case I would not argue that Orwell could not have developed his idea without the influence of C.S. Lewis or without the knowledge of his book. On the other hand, it is certain that he knew it because he wrote a short review of it for The Manchester Evening. ${ }^{1}$

Where did Orwell's concept of Newspeak come from? On the one hand, one could indicate Orwell's interest in the evolution of the English language in his lifetime, the evolution which triggered in him considerable anxiety, a fact which he expressed in a well-known essay entitled Politics and the English Language, written approximately three years prior to the publication of Nineteen Eighty-

\footnotetext{
* Professor, University of Lodz, Faculty of Philology, Department of English Drama, Theatre and Film; e-mail: andrzej.wicher@uni.lodz.pl

1 Cf. G. Orwell, The Scientists Take Over, George Orwell's review of C.S. Lewis, That Hideous Strength (1945), http://www.lewisiana.nl/orwell/ [accessed on: 20.04.2018].
} 
Four: A Novel, in which one could find the first description of the principles of Newspeak. In it, Orwell argued, using specific examples, that language, especially the language used by politicians, was more often used for concealing the truth rather than revealing it, and that political discourse was filled with carelessness, obscurity and vagueness. However, according to Orwell, those were not accidental flaws or weaknesses. From the point of view of cynical political pragmatics, they rather constituted advantages than flaws since they were used for arguing in favour of doubtful theses which would be difficult to defend if one applied strict logic and linguistic care. Obviously, even Newspeak was a tool used for concealing rather than revealing reality. Naturally, not every person who uses language incorrectly, mindlessly or sloppily is a witting accomplice of a totalitarian dictatorship, yet, in practice, such an approach to language objectively serves the dictatorship. That is because it leads to mental chaos and the blurring of distinct borders between notions, which can easily be used for political manipulation. According to Orwell: "the present political chaos is connected with the decay of language". ${ }^{2}$

In essence, some qualities of Orwell's Newspeak seem to amplify the effect of conceptual chaos. I am mainly referring to the slogans which Winston, the protagonist of Nineteen Eighty-Four: A Novel, saw on the building of the Ministry of Truth: "war is peace", "freedom is slavery", "ignorance is strength" , and which are repeated numerous times throughout the novel. The first two were based on the absurd or rather the seemingly absurd negation of an obvious truth; in a similar vein, one could invent such slogans as "night is day", " the crooked is straight", "short is long", etc. I wrote "seemingly absurd" as almost any absurdity can be, through some mental effort, presented as a paradox, i.e. an apparent absurdity. For example, for a nocturnal animal the night is, in some sense, what day is for a human, or rather a typical human, i.e. a time of peak activity. It was Euripides, a tragedian of classical Athens, who argued that in the other world everything is the opposite, and that that which we call life is considered there death, and everything which we call death is, from the point of view of that world, life. ${ }^{4}$ Naturally, that is a case of dialectic thinking understood as the unity of opposites while the

2 G. Orwell, Politics and the English Language, https://faculty.washington.edu/rsoder/EDLPS579/ HonorsOrwellPoliticsEnglishLanguage.pdf [accessed on: 20.04.2018].

3 G. Orwell, 1984, https://www.planetebook.com/free-ebooks/1984.pdf [accessed on: 20.04.2018], p. 6.

4 I am referring to a fragment which I only know from a German translation, from a lost tragedy by Euripides entitled Polyeidos. Cf. E. Rohde Psyche. Sehlenkult und Unsterblichkeitsglaube der Griechen [Psyche. The cult of the soul and belief in immortality of ancient Greeks], Alfred Kröner Verlag, Stuttgart, no publication date, p. 5:

Wer weiß denn, ob das Leben nicht ein Sterben ist, [Who knows whether living is really death] und, was wir Sterben nennen, drunten Leben heißt? [and whether death is thought to be living below?] 
original sources of that thinking are to be found in ancient Greece, e.g. in the quite cynical dialectics professed by some philosophers or stoic orators who often had the ambition of presenting absurd or false theses in a convincing manner. Paradoxically enough, stoics sometimes were more cynical than the philosophers of the Cynical school.

In the world of Orwell's novel, war was actually peace in the sense that the totalitarian regime depicted in it considered war, not peace, as a normal state, as war offers better opportunities than peace for maintaining strict control over society. However, at the metaphorical level, the notions of "war" and "peace" are sometimes difficult to differentiate. The Islamic notion of "jihad", often incorrectly translated as "holy war", may be understood in a completely non-military manner as an internal human struggle with our sinful nature, and such an understanding of jihad, as far as I know, is preferred by many Muslims. In the madrigals by the renowned Italian Baroque composer Claudio Monteverdi, there existed a recurring assertion that all lovers are warriors (Ogni amante è guerrier), which seems close to the thesis that love is war.

Finally, the slogan "freedom is slavery" seems an apt satire of the famous Marxist, definition of freedom: "freedom is the recognition of necessity", which, of course, can be understood in various manners, yet the fact remains that no one associates the notion of necessity with freedom, rather the opposite: if freedom allows one to choose an option, necessity, recognised or not, eliminates that freedom of choice. Then again, it would be difficult to deny the fact that there are situations when only one mode of operation is proper, while the rest, in accordance with moral precepts, should be rejected; in other words, the recognised necessity is not always something bad nor is it always contrary to the notion of freedom, unless one considers freedom within a completely anarchic and amoral framework. Saint Peter in the New Testament defined the free or rather the truly free man as " servants of God". ${ }^{5}$ On the one hand, paradoxical rhetoric, in fact, exists in the New Testament, e.g. in such well-known statements as that "the last shall be first", "for whosoever will save his life shall lose it", "if [a corn of wheat] die, it bringeth forth much fruit"8, etc. On the other, though, the Christian doctrine,

5 The First Epistle of Peter 2:16, eds. R. Carroll, S. Prickett, The Bible. Authorised King James Version, The New Testament, Oxford University Press, Oxford 1998, p. 286: As free, and not using your liberty for a cloke of maliciousness, but as the servants of God.

6 Gospel According to Matthew 20:16, The Bible. Authorised King James Version, The New Testament, ... p. 29.

7 Gospel According to Luke 9:24, The Bible. Authorised King James Version, The New Testament, ... p. 87 .

8 Gospel According to John 12:24, The Bible. Authorised King James Version, The New Testament, ... p. 134 . 
the Gospel According to Matthew to be precise, warns against dialectic excess, includes a strong recommendation of the stability of meaning, and stresses the value in binary oppositions: "Neither shalt thou swear by thy head, because thou canst not make one hair white or black. But let your communication be, Yea, yea; Nay, nay: for whatsoever is more than these cometh of evil."9 Being an atheist, Orwell obviously was not particularly concerned with what the Bible had to say on the matter, though one can clearly see that the slogans promoted by Orwell's Big Brother did not necessarily stem from, or could be associated with, any one particular anti-humanistic or anti-freedom tradition.

Post-modernism seems today the most common form of paradoxical and dialectic thinking. The Free Dictionary, a popular online dictionary, offers the following definition of post-modernism:

Of or relating to an intellectual stance often marked by eclecticism and irony and tending to reject the universal validity of such principles as hierarchy, binary opposition, categorization, and stable identity. ${ }^{10}$

It is clear that Orwell's Newspeak had much in common with the post-modern way of thinking, at least in the popular understanding of the term, especially in the aspect of questioning the legitimacy of binary oppositions, such as the already mentioned freedom vs. slavery or war vs. peace, though post-modernists prefer, in general, to question somewhat different binary oppositions, such as the differentiation between low and high cultures, truth vs. falsity, or male vs. female.

The "ignorance is strength" slogan is a natural reversal of the old saying that "knowledge is the key to power", well, maybe not quite so old as it has been assigned, in its Latin form of "Scientia potentia est", to Francis Bacon, an English philosopher who lived at the turn of the 17th century and wrote both in Latin and in English. The assertion that "ignorance is strength", though it sounds absurd, could hardly be considered a paradox in the world of Nineteen Eighty-Four: A Novel. It was a precise description of the reality if one interprets it as meaning: the ignorance of the ruled is the source of strength of the ruling class. Clearly, though, there is also a tradition of considering knowledge as useless baggage which weighs one down and hinders one's actions rather than being the source of strength and power. Shakespeare's Hamlet in closing his monologue which began with the words:

9 The Gospel According to Matthew 5:36-37, The Bible. Authorised King James Version, The New Testament, ... p. 8.

10 The Free Dictionary by Farlex, https://www.thefreedictionary.com/dictionary.htm [accessed on: 20.04.2018]. 
"to be or not to be", eventually concluded that:

Thus conscience does make cowards of us all,

And thus the native hue of resolution

Is sicklied o'er with the pale cast of thought;

And enterprises of great pitch and moment

With this regard, their currents turn awry,

And lose the name of action."

Excessive knowledge may also be dangerous, apparently, especially in crime literature which depicts characters who get killed "because they knew too much."

That shows how the basis of Big Brother's ideology came from tradition and is subject to rationalisation. That does not, however, prevent one from considering it as leading to madness and a total loss, through linguistic manipulation, of the ability to reliably describe the reality. Orwell himself said in that context about "controlled madness":

The Ministry of Peace concerns itself with war, the Ministry of Truth with lies, the Ministry of Love with torture and the Ministry of Plenty with starvation. These contradictions are not accidental, nor do they result from ordinary hypocrisy; they are deliberate exercises in doublethink. For it is only by reconciling contradictions that power can be retained indefinitely. In no other way could the ancient cycle be broken. If human equality is to be forever averted - if the High, as we have called them, are to keep their places permanently - then the prevailing mental condition must be controlled insanity.12

However, a question arises: can that insanity be controlled successfully? The total dialectics which seemed to exist in Big Brother's state could prevent even the most basic differentiations, such as right vs. left or up vs. down, without which a society would not be able to function.

Orwell's doublethink was, to a degree, a synonym of dialectics, or rather of that version of dialectics which was referred to as "the logic of illusion" (Kant's "Logik des Scheins"13) and which consisted of offering an impression that one believed that which one actually did not believe. In The Captive Mind,

11 Hamlet, 3.1.83-88, [in:] W. Shakespeare, Hamlet, ed. B. Lott, Longman, Burnt Mill, Harlow 1993, p. 99.

12 G. Orwell, 1984, p. 273.

13 Cf. J.Noller. Logik des Scheins. Kant über rationale Selbsttäuschung, https://www.academia. edu/38373262/Logik_des_Scheins_Kant_\%C3\%BCber_rationale_Selbstt\%C3\%A4uschung?a uto $=$ download [accessed on: 20.04.2018]. 
Czesław Miłosz developed, independently of Orwell's influence, his own version of "doublethink" which he referred to using a phenomenon known in Arabic as "ketman", which basically means hiding or masking oneself:

Even though the identification of the play with private thought-property is carried very far, a large residue of unassimilated matter remains which forces one to keep alert. A constant and universal masquerade creates an aura that is hard to bear, yet it grants the performers certain not inconsiderable satisfactions. To say something is white when one thinks it black, to smile inwardly when one is outwardly solemn, to hate when one manifests love, to know when one pretends not to know, and thus to play one's adversary for a fool (even as he is playing you for one) - these actions lead one to prize one's own cunning above all else. Success in the game becomes a source of satisfaction. Simultaneously, that which we protect from prying eyes takes on a special value because it is never clearly formulated in words and hence has the irrational charm of things purely emotional. Man takes refuge in an inner sanctuary which is the more precious the greater the price he pays in order to bar others from access to it. ${ }^{14}$

It is interesting that Miłosz wrote about "pretending not to know", i.e. he indicated a major aspect of Orwell's slogan of "ignorance is strength." In Miłosz's approach, that which offered certain strength was not so much ignorance itself as the act of feigning it. That is undoubtedly logical, as fundamentally ignorance is a weakness. Weakness itself is not associated with power or strength, but a situation where one cunningly pretends to be weaker than one is in reality may definitely evoke such associations.

However, Orwell defined "doublethink"15 as: "Doublethink means the power of holding two contradictory beliefs in one's mind simultaneously, and accepting both of them"16. Therefore, unlike in the case of Miłosz's "ketman", a proponent of "doublethink" did not so much conceal their true views explicitly professing, through caution, those which they considered false, while nurturing inside those which they considered to be true, but rather they themselves could no longer differentiate a false view from a true one. That may be because pretending had become so habitual for them that the mask became like an alternative face and they could no longer decide which was fake and which was real. "Ketman" is a strategy of people who decided to outsmart the totalitarian hegemon, while "doublethink" is rather a desperate act of defence by people who know no other

14 C. Miłosz, The Captive Mind, https://issuu.com/bouvard6/docs/milosz_-_the_captive_mind [accessed on: 20.04.2018].

15 G. Orwell. 1984 , p. 270.

16 Ibidem. 
way to overcome the conflict between the rule of mind and reason and the rule of an arbitrary authority which thinks nothing of reason or the natural law. However, it seems that in practice "doublethink" is more effective than "ketman", a person who "doublethinks" will easily and with full conviction defend, if it is convenient for them, false views while a person who uses "ketman" may, through carelessness, reveal their true views.

Obviously, totalitarian authorities or their agents could not have functioned without "doublethink". All tyrants like to think they can shape people's minds and attitudes as they please, so when they say that two plus two equals five, no one can deny that. At the same time, though, no authorities can in practice operate on the basis of the principle that two plus two equals five. That was probably the source of the rupture in the fabric of Orwell's totalitarian world symbolised by the division into the Outer Party, which consisted of, or it should have consisted of, people turned into mindless automatons always ready to believe that two plus two equalled five, and the Inner Party, which fulfilled a controlling role and had to act on a relatively realistic evaluation of the reality. In a totalitarian system, access to the truth is just as limited as access to luxury goods, and the Inner Party benefited from it. Thus, truth in the world of Nineteen Eighty-Four functioned as a fairly inaccessible good, just like premium ham, expensive alcohol or fashionable clothing.

Of course, neither members of the Outer Party nor even the proles, i.e. simple labourers, could function in following the principle that two plus two equals five, yet their inferior status was the reason why they were forced to at least give the impression that even among themselves they believed the often absurd theses of official propaganda. Only the members of the Inner Party could, from time to time at least, indulge in some luxury of "singlethink", i.e. a healthy realisation that things were as they were. Without the followers of "singlethink" it would be impossible to manage any society, and it is only logical that they constitute a high layer, yet, at the same time, they constitute the source of the threat to a totalitarian system as they value reason over obedience. In Orwell's novel, O'Brien was one of those; in my opinion he was a fairly unconvincing character since, despite knowing the weaknesses of the system led by Big Brother well, he was, despite appearances, its loyal servant. Such characters surely exist, yet they seem quite unique.

\section{2}

Therefore, one of the sources of Orwell's Newspeak was certainly the European dialectic tradition and the tradition of paradoxical thinking put at the service of a dictatorship. However, it seems that Newspeak also had other affiliations. One of those could have been the association of the notion of Newspeak with the fashion 
for artificial languages, which were developed from the end of the 19th century and in the first half of the 2oth century. I am referring to, of course, Esperanto, the Ido language and, finally, Novial, created in 1928 by Otto Jespersen, a Danish linguist, which even resembled Newspeak in its name, since the acronym NOVIAL means "new international auxiliary language" ${ }^{17}$ I am not suggesting that the very notion of such languages carries some ominous content or aspects which would make those languages a convenient instrument of totalitarian rule. What I am suggesting is that they might have provided Orwell's with indirect inspiration for creating Newspeak.

What makes them seem similar to Newspeak is mainly their tendency to simplify the existing natural languages. That is, obviously, a completely understandable tendency. Artificial languages are not supported by powerful institutions serving nation states as the latter have no interest in supporting an idea which might, at least potentially, diminish the importance of national languages, especially in the case of national languages with international ambitions, i.e. those which represent the largest world powers and the greatest wealth. Not being able to count on such support, an artificial language must possess other advantages, the most easily achievable of which are simplicity and regularity through which, at least in theory, such languages are much easier to learn than natural languages. I wrote "in theory" because polyglots are usually people who thrive on irregularities and the intricacies of natural languages, more or less in keeping with the principle that ambitious mountaineers are not interested in easily conquerable mountains. Therefore, artificial languages do not seem attractive either for opportunists keen on joining a side winning the international rivalry or aficionados interested in a language itself regardless of the material success achievable through using it. Promoters of artificial languages should rather be idealists who believe in their triumph yet who realise that it cannot occur immediately or in any foreseeable future, that it is, in other words, a matter of a "long march".

A somewhat similar situation existed in the case of Newspeak in Orwell's novel. A character by the name of Syme was a kind of a prophet of Newspeak, who thought in the long temporal perspective:

"The Revolution will be complete when the language is perfect. Newspeak is Ingsoc and Ingsoc is Newspeak," he added with a sort of mystical satisfaction. "Has it ever occurred to you, Winston, that by the year 2050, at the very latest, not a single human being will be alive who could understand such a conversation as we are having now?" [... "By 2050 - earlier, probably - all real knowledge of Oldspeak will have disappeared. The whole literature of the past will have been destroyed. Chaucer, Shakespeare, Milton, Byron - they'll exist only in Newspeak versions, not merely chan-

17 Wikipedia, https://en.wikipedia.org/wiki/Novial [accessed on: 20.04.2018]. 
ged into something different, but actually changed into something contradictory of what they used to be. ${ }^{18}$

Orwell applied a kind of an extrapolation of the notion of artificial language. It was intended by its creators as a means of expressing the entire richness of human thought included in artistic, philosophical and scientific literature using simplified means. It seems that Orwell viewed such an assumption as naive, and based on the false belief that it is be possible to separate form from content. As he posited in his essay Politics and the English Language: if thought corrupts language, language can also corrupt thought (https://faculty.washington.edu/). Therefore, a simplified language must lead to simplifications, i.e. primitivisation and distortion of content expressed by the language. The very notion of Newspeak was based on imagining a situation where the artificial language did not need to depend on a rather small group of enthusiasts because the apparatus of state measures and state violence was, quite unexpectedly, employed in implementing it.

Obviously, since Newspeak was, in Orwell's world, not so much an artificial language, but rather a radically simplified version of English, it was particularly similar to the concept of so-called Basic English proposed by Ch.K. Ogden. In Basic English it was supposedly possible to use 850 words to express the content which in normal English would require the application of approx. 20,000 words. Interestingly enough, Orwell was for a few years a fervent supporter of Basic English as he appreciated the fact that it promoted conciseness and simplicity instead of overblown rhetoric. However, eventually, Orwell turned against Basic English and mocked the notion in his very own creation: Newspeak.

Orwell provided an example of using Newspeak which seemed to combine the features of the so-called telegraphic style with the bureaucratic jargon which consisted of using radical and surprising abbreviations and omitting verbs, which was supposed to give the impression of greater precision:

times 17.3 .84 bb speech malreportedafrica rectify

times 19.12 .83 forecasts 3 yp 4 th quarter 83 misprints verify current issue

times 14.2.84 miniplentymalquoted chocolate rectify

times 3.12.83 reporting bb dayorderdoubleplusungood

refs unpersons rewrite fullwiseupsubantefiling. ${ }^{19}$

The result is gibberish completely incomprehensible to a normal person, a text which can only be deciphered by someone who knows the situational context and

18 G. Orwell, 1984, pp. 67-68.

19 G. Orwell, 1984, p. 49. 
the mentality of the authors of such texts. The final two lines were translated into Oldspeak as follows:

The reporting of Big Brother's Order for the Day in the Times of December 3rd 1983 is extremely unsatisfactory and makes references to non-existent persons. Rewrite it in full and submit your draft to higher authority before filing. ${ }^{20}$

"Ungood" does not exist in English even though there are other blends with the negative suffix "un", e.g. "unlikely" or "unhealthy". It seems that Orwell alluded in that instance to a feature of Esperanto. For example, the adjective "sana" in Esperanto means "healthy" while "malsana" means "sick" or more precisely "unhealthy" as the "mal" prefix entails a negative meaning, similarly to the English "un", whereas Esperanto, as far as I know, does not include an adjective which corresponds to the word "sick" and does not include the "mal" prefix. Similarly, "bad" in Esperanto is "malbona" basically meaning "ungood" since "good" is "bona". Clearly, Ludwik Zamenhof, the language's creator, decided that pairs of opposing terms such as "healthy-sick" or "good-bad" were redundant complications of the linguistic system since the oppositions could be expressed in a more regular manner less strenuous on one's memory, using pairs signifying "healthy vs. unhealthy" or "good vs. ungood". The problem is, of course, that any simplification of a system very often causes its impoverishment, and it seems that Orwell was warning against just that.

Zamenhof, having grown up in Białystok, Poland, where, on a regular basis, he encountered at least two if not three Slavic languages, i.e. Polish, Russian and Belarusian, and two Germanic languages, i.e. German and Yiddish, could also have been impressed by the fact that the Slavic prefix "nie" and the German prefix "un" very easily and frequently connect with adjectives, much more often than the English prefix "un", which is why the form "ungood" does not exist in English, while in Slavic languages its counterparts are quite common, just like the German form "ungut". By the same token, one cannot, on the basis of the English adverb "far" create the form "unfar", if one were to express the opposite of "far", i.e. a word corresponding to the Polish adverbs of "blisko" [close] or "niedaleko" [not far]. It would usually be necessary to use words structurally completely unrelated to the adverb "far", such as "close", "closely", "near" or "nearby", possibly use a periphrastic form of "not far off" or a similar one, which is possible only in some situations.

Newspeak's Esperanto-inspired forms could also include such verbs as "to malreport" or "to malquote" However, Orwell was not consistent and used in Newspeak the word "misprint", which means he used a different negative suffix, 
i.e. "mis". If Orwell had proceeded as consistently as Zamenhof did, he would have, obviously, written "malprint". In general, Orwell used the notion of an artificial language to create a sense of foreignness or even inhumanity of the language, which, one could say, was, paradoxically, the more foreign the more often it used existing words, or rather their shreds. It was, of course, in no case a satire on any specific language, e.g. Esperanto, but rather a vision of the potential consequences of implementing an artificial language. ${ }^{21}$

The formulation of bold yet quite unappealing acronyms such as "miniplenty" denoting the Ministry of Plenty might, in turn, suggest their Russian, or rather Soviet, inspiration. Those had already been mocked by Vladimir Mayakovsky when he created the character of director Pobedonosikov in his play The Bathhouse, translated into Polish as Naczdyrdups, expanded as "Naczelny Dyrektor dla uzgadniania pewnych spraw" [Chief Director for establishing some matters]. Another such acronym is the well-known, though carrying terrible associations, word Gulag derived from "Glavnoye upravleniye lagerey" [Main Administration of Camps], or "profsoyuz", which means a professional association, or rather a trade union. If transferred into the Polish language, it would be necessary to refer to a trade union [związek zawodowy] as "związawód", "zawozwiąz" or the like, while in English such form as, for example, "trunions" instead of "trade unions" would have to be postulated. Of course, the internet offers even more monstrous examples of these Soviet-Russian acronyms.

Another possible source of inspiration for creating Newspeak could have obviously been the well-known work of Jonathan Swift, Gulliver's Travels. Part III of the novel, filled with mental experiments, includes a project of a universal language invented by the scientists of the Grand Academy of Lagado, full of ambitious scientists who had all types of ingenious and, to put it bluntly, stupid ideas, e.g. to extract sunlight from cucumbers or soften marble to produce a pin cushion:

21 At this point, I should mention an article by J. Pool and B. Grofman entitled Language as Political Control: Newspeak Revisited, in which the authors conducted a detailed comparison of Orwell's Newspeak with Esperanto, e.g. by discussing the issue of negative prefixes, and arrived at a rather surprising conclusion that in the real world an attempt at imposing something like Newspeak on a community would rather facilitate than hinder the formulation of opposition thoughts against the ruling regime or system. I think that theoretically that might be possible, yet in practice, in a situation of information monopoly and an incessant influx of propaganda content, an individual, in my opinion, would be subjected to such a strong pressure that the automatic and formulaic nature of Newspeak, i.e. its inherent ease of formulating simple communications, would rather work as suggested by Orwell, to the benefit of the regime and official propaganda. Cf. J. Pool, B. Grofman, Language as Political Control: Newspeak Revisited, https://old.panlex.org/pubs/etc/langpolcontrol.pdf [accessed on: 20.04.2018]. 
We next went to the school of languages, where three professors sat in consultation upon improving that of their own country.

The first project was, to shorten discourse, by cutting polysyllables into one, and leaving out verbs and participles, because, in reality, all things imaginable are but norms.

The other project was, a scheme for entirely abolishing all words whatsoever; and this was urged as a great advantage in point of health, as well as brevity. For it is plain, that every word we speak is, in some degree, a diminution of our lungs by corrosion, and, consequently, contributes to the shortening of our lives. An expedient was therefore offered, "that since words are only names for things, it would be more convenient for all men to carry about them such things as were necessary to express a particular business they are to discourse on." And this invention would certainly have taken place, to the great ease as well as health of the subject, if the women, in conjunction with the vulgar and illiterate, had not threatened to raise a rebellion unless they might be allowed the liberty to speak with their tongues, after the manner of their forefathers; such constant irreconcilable enemies to science are the common people. However, many of the most learned and wise adhere to the new scheme of expressing themselves by things; which has only this inconvenience attending it, that if a man's business be very great, and of various kinds, he must be obliged, in proportion, to carry a greater bundle of things upon his back, unless he can afford one or two strong servants to attend him. I have often beheld two of those sages almost sinking under the weight of their packs, like pedlars among us, who, when they met in the street, would lay down their loads, open their sacks, and hold conversation for an hour together; then put up their implements, help each other to resume their burdens, and take their leave.

But for short conversations, a man may carry implements in his pockets, and under his arms, enough to supply him; and in his house, he cannot be at a loss. Therefore the room where company meet who practise this art, is full of all things, ready at hand, requisite to furnish matter for this kind of artificial converse.

Another great advantage proposed by this invention was, that it would serve as a universal language, to be understood in all civilised nations, whose goods and utensils are generally of the same kind, or nearly resembling, so that their uses might easily be comprehended. And thus ambassadors would be qualified to treat with foreign princes, or ministers of state, to whose tongues they were utter strangers. ${ }^{\mathbf{2 2}}$

22 J. Swift, Gulliver's Travels, https://www.gutenberg.org/files/829/829-h/829-h.htm [accessed on: 20.04.2018]. 
Swift might had provided Orwell with two basic ideas. Firstly, that an artificial language may be based on a radical simplification and the impoverishment of natural language obviously in order to make the learning of such a language easier and more pleasant. Secondly, the simplification, contrary to expectations, does not necessarily lead to better mutual understanding, rather the formation of messages full of obscurity and ambiguity, resembling as a matter of fact complete gibberish. The fact that Orwell's Newspeak consists almost exclusively of nouns may also, in my opinion, have also been adopted from the language, or rather the pseudo-language, promoted by the researchers at the Grand Academy of Lagado. The dream of a universal language intended to overcome the curse of the Tower of Babel could, of course, be identified in other epochs as well.

\section{3}

The thoughts on language included in C.S. Lewis's science fantasy novel That Hideous Strength also seem noteworthy in the context of Orwell's Newspeak. It is certain that Orwell knew Lewis's novel since he was its reviewer, and a rather critical one. It was published only four years prior to Nineteen Eighty-Four, in 1945. Lewis was, of course, a character quite different from Orwell. First of all, unlike Orwell, he was a classical scholar, an historian of English literature, a researcher of the Middle Ages and a specialist in the Renaissance, with strong affiliations with the universities of Oxford and Cambridge. Secondly, Lewis was a conservative Christian who, similarly to Orwell, rejected communism, especially its Soviet variety, yet did not share Orwell's sympathy towards the so-called democratic socialism, i.e. an attempt at implementing the leftist utopia while avoiding the problems of the communist system. Lewis generally rejected all leftist ideas. He was certainly a man of the conservative right, a defender and propagator of traditionally understood Christianity. He was often criticised, even during his lifetime, for his alleged "backwardness" and "reactionarism", though he avoided direct involvement in any political disputes or party politics. Yet his anti-utopian attitude seemed doubtful since, by being a Christian, he believed in the existence of a perfect world, even though he probably rather placed it outside the empirical world. Today, Lewis is probably best known as the author of The Chronicles of Narnia, a series of fantasy novels intended mainly for children and young adults. That Hideous Strength was written a little earlier than The Chronicles of Narnia and in some instances it resembles the latter considerably (e.g. considering the division depicted in it between the alliance of the forces of good fighting the united forces of evil), certainly more similar than Lewis's two other science fiction novels, together with which it formed the so-called Space Trilogy: Out of the Silent Planet and Perelandra. 
It would be difficult to summarise That Hideous Strength as there so many things happening in it and it includes a whole host of characters. In the most general terms, it is a story of the efforts to neutralise a pseudo-scientific research centre which intends to seize power over the world and introduce a very cruel form of totalitarian dictatorship. Fortunately, the centre, with the strongly ironic name N.I.C.E. (National Institute of Coordinated Experiments), does get destroyed, though it probably would not have been possible without an intervention of clearly supernatural powers. Despite its name, there was nothing nice about the institution; it was rather a collection of exceptionally despicable individuals who claimed to have been able to develop a programme for a scientific and progressive resolution of all social problems. That rather blunt irony was also present in Orwell's names: the Ministry of Plenty (whose task was to increase shortages) and the Ministry of Truth (whose task was to promote lies).

Mark Studdock, the protagonist in Lewis's novel, is devoid of the positive qualities possessed by Nineteen Eighty-Four's Winston Smith, though he is not a fundamentally bad person, rather someone average and conventional. His main obsession, which nearly brought him to complete moral degeneration, is his urge, snobbish in its nature, to enter the so-called inner circle, i.e. the informal elite which decided about the most important issues in an organisation or an institution. In the case of Studdock, that institution was Bracton College, part of a small provincial university in Edgestow (completely fictional), where he worked as a sociologist and academic teacher; only later did he work at N.I.C.E., the seat of which was located in a forest within an area which originally belonged to Bracton College and neighbouring areas. The notion of the inner circle and its presentation in Lewis's novel could have inspired Orwell to create the division into the Inner and Outer Party, so important in Nineteen Eighty-Four.

However, coming back to strictly linguistic issues, those played a major role in Lewis's novel. The very title suggests just that. That hideous strength was a quote from an obscure 16th-century epic poem by David Lyndsay, best known as the author of the morality play A Satire of the Three Estates. The phrase referred to the Biblical Tower of Babel, which seems strange until one realises that, in Scottish English, the word "strength" may, apart from its normal meanings, denote a fortress, or, in this case, a tower. The Polish title of Lewis's novel should actually read "Ta ohydna / straszna forteca / wieża" [That Hideous / Terrible Fortress / Tower], and the curse of the Tower of Babel, i.e. the mixing of languages is basically, despite some appearances, the main, though certainly not the only, topic of the book.

The theme of false usage of language is clearly visible in the first scene when Mark Studdock meets John Wither, a deputy director at N.I.C.E. Wither is only formally a "deputy director", while in fact everything in the institution seems to depend on him, unless one argues that its true directors are the so-called 
Macrobes, or one of those creatures of a clearly demonic and diabolic nature with which Wither often has encounters. Wither, whose name evokes the phenomena of drying out, wilting, dying out, that is, phenomena related to diminishing vitality, is a seemingly polite, obsequious even, person, yet in reality no one should expect of him any normal human reactions. He seems the embodiment of the description in Shakespeare's Hamlet: "That one may smile, and smile, and be a villain." ${ }^{23}$ Mark tried to learn from Wither what his responsibilities at the N.I.C.E. would be, yet Wither responded only in circular evasive sentences which seemed to be very kind yet lack any clear content. Eventually Mark was seized by fear because it seemed to him that his interlocutor considered the questions he was faced with to be proof of the inquirer's lack of intelligence which was why they did not deserve to be answered in any concrete manner. Wither said things like:

I think, Mr. Studdock, we have already mentioned elasticity as the keynote of the Institute. Unless you are prepared to treat membership as ...er... a vocation rather than a mere appointment, I could not conscientiously advise you to come to us. There are no watertight compartments. I fear I could not persuade the committee to invent for your benefit some cut-and-dried position in which you would discharge artificially limited duties and, apart from those, regard your time as your own. [...] We are, as I have said before, more like a family, or even, perhaps, like a single personality. ${ }^{24}$

Only one thing became clear: that work at the N.I.C.E. required full availability, one's agreement to be a cog in some grand mechanism which had no clearly defined goals either at the general or the specific level. Even if such goals existed, an ordinary employee was apparently not supposed to know too much about them. Mark tried several times to interrupt Wither's ceaseless flow, yet that triggered Wither's clear discontent. Wither liked talking but he disliked listening. ${ }^{25}$

23 W. Shakespeare, Hamlet, (1.5.108), p. 45

24 C.S. Lewis, That Hideous Strength. A Modern Fairy Tale for Grown-Ups, Harper Collins Publishers, London 2005, p. 155.

25 There is an article by an American author Kath Filmer entitled That Hideous 1984. The Influence of C.S. Lewis "That Hideous Strength" on Orwell's "Nineteen Eighty Four" which offered many valuable remarks on both novels and their similarities, yet the author focussed on some other issues than the ones discussed in this article. Additionally, I do not fully agree with her, especially when she wrote: "the spectral Wither, Deputy Director of N.I.C.E., never utters a meaningful sentence, though this fact is disguised by his circumlocutions." The fragment of Wither's statement I quoted earlier is, in my opinion, completely logical, though I must admit that the logic is rather elliptical. Nonetheless, Wither made it quite clear that an employee of the institution he managed would not be entitled to privacy and would have to be completely available, just like the citizens of Orwell's Oceania. Wither's demonic air seemed to stem not 
Later one learns that, in general, the director was not able to stop his activities. He practically did not sleep; at nights he strolled the halls of the institute building and he seemed to be everywhere and monitor everything, and yet it was impossible to establish any personal contact with him as he behaved as if he were sleepwalking and his eyes were expressionless. Moreover, one could get the impression that he was able to appear in several places at the same time.

Such elements as the quaint behaviour of the deputy director which consisted of a kind of absent omnipresence and his mode of speaking which had little in common with real communication and was rather used for concealing reality might have, in my opinion, somewhat helped Orwell create the character of Big Brother and Newspeak. However, Orwell did not accept the supernatural aspects of the world depicted in Lewis's novel. According to Orwell, Lewis's book "would have been stronger without the supernatural elements." Particularly, Orwell objected to the ending in which N.I.C.E. is overthrown by divine intervention:

"[Lewis] is entitled to his beliefs, but they weaken his story, not only because they offend the average reader's sense of probability but because in effect they decide the issue in advance. When one is told that God and the Devil are in conflict, one always knows which side is going to win. The whole drama of the struggle against evil lies in the fact that one does not have supernatural aid."26

One should note, though, something that Orwell seemed to have missed, i.e. that, first of all, the supernatural intervention in Lewis's novel was not only an outcome of the author's world view, but rather a consequence of using the Biblical story of the Tower of Babel as the book's original myth, and secondly, Orwell seemed to overlook the fact that the supernatural intervention was, in line with the Biblical tradition, a punishment, and a rather severe one for that matter, for human pride.

Lewis did, however, somewhat modify the Biblical message in his novel. The penalty, i.e. the curse of the Tower of Babel, did not result in a situation in which a multitude of languages emerged from the original language, but rather in that a language, any language, though it is English in the case of this novel, became afflicted by a peculiar disease. As a result of it, language was not used for communication or objective description of reality, but for dominating and

from the gibberish of his statements, but from the fact that under the pretence of kindness he concealed a total lack of empathy and complete coldness. Cf. K. Filmer, That Hideous 1984. The Influence of C.S. Lewis "That Hideous Strength" on Orwell's "Nineteen Eighty Four", https:// online.liverpooluniversitypress.co.uk/doi/abs/10.3828/extr.1985.26.2.160?journalCode=extr [accessed on: 20.04.2018].

26 Wikipedia, http://en.wikipedia.org/wiki/That_Hideous_Strength [accessed on: 20.04.2018]. 
imposing one's view of the world onto others. Thus, the curse of the Tower of Babel was somewhat repeated, but within a single language. In it, there formed private, or rather cultist, "minor languages" which only pretended to continue to belong to one language, because in reality they surrounded themselves with a wall barring people who did not use them. The sickness was depicted as a developing phenomenon which continued to assume ever more extreme forms.

Eventually, characters who represented the forces of evil in That Hideous Strength fell prey to utter gibberish, which was a logical consequence of the incessant destruction of language which they practiced. The multitude of mutually incomprehensible, yet in themselves fully operational, languages constitutes a parody of unity which prevents any understanding either inside or outside a group. As a result, some people seized by the N.I.C.E. ideology trampled each other, while the rest were killed by wild animals such as tigers and bears that broke out from the cages in which they were kept for some vague cruel experiments:

There were dead and dying bodies everywhere by now, for the scrum was by this time killing as many as the beasts. And always from all sides went up the voices trying to shout to those beyond the door, "Quick! Quick! Hurry!" but shouting only nonsense. Louder and louder grew the noise at the door. As if in imitation a great gorilla leaped on the table where Jules had sat and began drumming on its chest. Then, with a roar, it jumped down into the crowd. ${ }^{27}$

The role played by the animals in that peculiar massacre, often compared to the end of the world described in the Apocalypse ${ }^{28}$, seems quite logical. Human beings do not become animals once they become deprived of a human language, as animals possess their own ways of inarticulate communication, developed throughout centuries and millennia. Humans suddenly deprived of their ability to use speech become something far worse than an animal. They become a pathetic parody of an animal, while animals, the higher ones, of course, can be thought of as averse to being parodied or mocked. ${ }^{29}$

Apropos of animals: the image of the quasi-animal gibberish in Lewis's novel could suggest Orwell's concept of so-called duckspeak, i.e. a manner of speaking in which the pace, mindlessness and automatism were to resemble a duck quacking,

27 C.S. Lewis, That Hideous..., p. 485.

28 Vide R.L. Purtill, Lord of the Elves and Eldils. Fantasy and Philosophy in C.S. Lewis and J.R.R. Tolkien, Ignatius Press, San Francisco 2006, p. 17.

29 There have been recorded cases of gorillas in zoos attacking people who parodied their behaviour. Vide: Goryl próbował zaatakować, kiedy dziecko uderzało pięściami w klatkę piersiowa, "Gazeta Wyborcza" 2015, 18.04, http://wyborcza.pl/1,75399,17776188,Goryl_probowal_ zaatakowac_kiedy_dziecko_uderzalo.html [accessed on: 20.04.2018]. 
though, probably, ducks would not have agreed with that if they could speak. Naturally, duckspeak was just one aspect of Newspeak:

For the purposes of everyday life it was no doubt necessary, or sometimes necessary, to reflect before speaking, but a Party member called upon to make a political or ethical judgement should be able to spray forth the correct opinions as automatically as a machine gun spraying forth bullets. ${ }^{30}$

Clearly, even though Orwell was far from Lewis's Biblical and metaphysical mode of thinking, he did accept the latter's way of thinking about language. The use of jargon, which offers ready-made linguistic and mental patterns, leads to, in extreme cases, complete dehumanisation of language. It is symptomatic that in the scene of the final mixing of the language in That Hideous Strength, the leader of N.I.C.E. referred to as the deputy director, only after a long while realised that something was wrong with the language used by the speaker since "he had never expected the speech to have any meaning as a whole..."31

However, the animal which Lewis seemed to suggest in the scene of the triumph of utter gibberish was not the good old duck, but rather a snake. I am referring to what happens in Book 10 of Paradise Lost by John Milton when Satan wanted to boast in the company of other devils of his triumph over the gullible man whom he had managed to convince to violate God's bans:

He would have spoke,

But hiss for hiss returned with forkèd tongue

To forkèd tongue, for now were all transformed

Alike, to serpents all, as accessories

To his bold riot. ${ }^{32}$

C.S. Lewis, being an outstanding specialist in Milton's works, could have been referring to the memorable passage about the transformation of the community of fallen angels devoid of human speech into serpents when he was developing the vision of the modern version of the curse of the Tower of Babel. It would be also difficult not to notice that Milton's taking away of Satan's and his minions' speech was a reversal and a parody of the descent of the Holy Spirit described in

30 G. Orwell, 1984, p. 388.

31 C.S. Lewis, That Hideous..., p. 477.

32 J. Milton, Paradise Lost, ed. D. Bush, Milton, Poetical Works, Oxford University Press, London, Oxford 1974, *X, 517-521), p. 410. 
the Acts of the Apostles ${ }^{33}$, which in turn was, to some extent, a reversal of the curse of the Tower of Babel as it symbolised the restoration of unity and the ability to understand many languages.

Then, if one were to consider Orwell's Nineteen Eighty-Four from the theological point of view, one could indicate, putting aside its entirely secular nature and its author's atheism, a kind of a parody or paraphrase of Christian language in the often-quoted ending: "He was back in the Ministry of Love, with everything forgiven, his soul white as snow. [...] But it was all right, everything was all right, the struggle was finished. He had won the victory over himself. He loved Big Brother." ${ }^{34}$ In that case, however, the words, which could have come from a biography of a saint or from a description of some mystical union with God ${ }^{35}$, if one assumes that Big Brother is a metaphor for God, meant the protagonist's surrender in the face of the totalitarian state and political and psychological terror used by it. It clearly conveyed deep and radical pessimism, unavailable for Christians like C.S. Lewis.

In summary, I can conclude that Orwell's book can be associated with many other texts which might have inspired him. In the case of The Captive Mind, there could, of course, be no influence of Miłosz on Orwell's novel as The Captive Mind was published in 1951, i.e. when Orwell had already died. One could rather discuss the possible influence of Orwell on Miłosz. What particularly links Nineteen EightyFour with C.S. Lewis's That Hideous Strength was, in my opinion, its deep concern with the problem of language broken and dehumanised by a totalitarian system. The cure, despite the differences between the two authors, was to return to the basic humanistic values associated with the emotions of friendship and love, though in Orwell's novel even sex was an act of rebellion against the totalitarian rule and a turn to the past not yet spoiled by the forces of the totalitarian revolution. Yet the measure was, in the long run, insufficient in the face of the power of Big Brother; in Lewis's novel, it lead to success, but only through a miracle, i.e. a supernatural intervention.

33 Cf. Acts of the Apostles 2:1-11, The Bible. Authorised King James Version, The New Testament... p. 148

34 G. Orwell, 1984, pp. 375-376.

35 They might have included an ironic allusion to a passage from Revelations of Divine Love by the mediaeval English mystic Julian of Norwich: "Sin is behoveable but all shall be well, and all shall be well, and all manner of things shall be well." The Shewings of Julian of Norwich, ed. G.R. Crampton, Medieval Institute Publications, Kalamazoo, Michigan 1994, p. 72. 


\section{Bibliography}

The Bible. Authorised King James Version, The New Testament, eds. Robert Carroll, Stephen Prickett, Oxford University Press, Oxford 1998.

Lewis Clive S., That Hideous Strength. A Modern Fairy Tale for Grown-Ups, Harper Collins Publishers, London 2005.

Milton John, Poetical Works, Oxford University Press, London, Oxford 1974.

Miłosz Czesław, The Captive Mind, Penguin Classics, London 2001.

Orwell George, Nineteen Eighty-Four, Penguin Books, London 1990.

Purtill Richard L., Lord of the Elves and Eldils. Fantasy and Philosophy in C.S. Lewis and J.R.R. Tolkien, Ignatius Press, San Francisco 2006.

Rohde Erwin, Psyche. Sehlenkult und Unsterblichkeitsglaube der Griechen [Psyche.

The cult of the soul and belief in immortality of ancient Greeks], Alfred Kröner

Verlag, Stuttgart, no publication date.

Shakespeare William, Hamlet, ed. Bernard Lott, Longman, Burnt Mill, Harlow, 1993. The Shewings of Julian of Norwich, ed. G.R. Crampton, Medieval Institute Publications, Kalamazoo, Michigan 1994.

\section{Internet resources}

Filmer Kath, That Hideous 1984. The Influence of C.S. Lewis "That Hideous Strength" on Orwell's "Nineteen Eighty Four", https://online.liverpooluniversitypress.co.uk/ doi/abs/10.3828/extr.1985.26.2.160?journalCode=extr [accessed on: 20.04.2018].

Goryl próbował zaatakować, kiedy dziecko uderzało pięściami w klatkę piersiową, „Gazeta Wyborcza” 2015, 18.04, http://wyborcza.pl/1,75399,17776188,Goryl_probowal_zaatakowac_kiedy_dziecko_uderzalo.html [accessed on: 20.04.2018].

Noller Jörg, Logik des Scheins. Kant über rationale Selbsttäuschung, https://www.academia.edu/38373262/Logik_des_Scheins_Kant_\%C3\%BCber_rationale_Selbstt \%C3\%A4uschung?auto=download [accessed on: 20.04.2018].

Orwell George, 1984, https://www.planetebook.com/free-ebooks/1984.pdf [accessed on: 20.04.2018].

Orwell George, Politics and the English Language, https:/faculty.washington.edu/ rsoder/EDLPS579/HonorsOrwellPoliticsEnglishLanguage.pdf [accessed on: 20.04.2018].

Orwell George, The Scientists Take Over, George Orwell's review of C.S. Lewis, That Hideous Strength (1945), http://www.lewisiana.nl/orwell/ [accessed on: 20.04.2018].

Pool Jonathan, Grofman Bernard, Language as Political Control: Newspeak Revisited, https://old.panlex.org/pubs/etc/langpolcontrol.pdf [accessed on: 20.04.2018].

Swift Jonathan, Gulliver's Travels, https://www.gutenberg.org/files/829/829-h/829-h. htm [accessed on: 20.04.2018]. 
The Free Dictionary by Farlex, https://www.thefreedictionary.com/dictionary.htm [accessed on: 20.04.2018].

Wikipedia, https://en.wikipedia.org/wiki/Novial [accessed on: 20.04.2018].

Wikipedia, http://en.wikipedia.org/wiki/That_Hideous_Strength [accessed on: 20.04.2018].

Andrzej Wicher

\section{Porównanie koncepcji Nowomowy w powieści Rok 1984 George'a Orwella ze sposobem myślenia o języku w powieści Ta ohydna siła C.S. Lewisa}

\section{Streszczenie}

Celem artykułu jest zbadanie wybranych źródeł inspiracji, które mogły posłużyć G. Orwellowi do stworzenia koncepcji sztucznego języka zwanego Nowomową, który w powieści Rok 1984 ukazany jest jako skuteczne narzędzie zniewolenia i kontrolowania myśli w ręku totalitarnej władzy. Autor omawia w tym kontekście możliwe związki między Nowomową a rzeczywiście istniejącymi sztucznymi językami, takimi jak Esperanto. Wskazane są również podobieństwa i różnice między Orwellowską koncepcją „dwójmyślenia” a pojęciem „ketmanu” zdefiniowanym w książce Czesława Miłosza pt. Zniewolony umysł. Jednak główny nacisk położony jest na związki między powieścią Orwella a fantastyczno-naukową powieścią C.S. Lewisa pod tytułem Ta ohydna siła. Wiadomo, że Orwell książkę Lewisa znał i nawet ją zrecenzował. Istnieje wiele bardziej i mniej oczywistych podobieństw między tymi dwoma wybitnymi wizjami zdegenerowanego języka, który służy bardziej politycznej manipulacji niż wzajemnemu zrozumieniu.

Słowa kluczowe: G. Orwell, C.S. Lewis, totalitaryzm, dehumanizacja, psucie języka, sztuczny język, eksperymentowanie w dziedzinie języka. 


\section{A comparison between the concept of Newspeak in George Orwell's Nineteen Eighty-Four: A Novel and the way of thinking about language in C.S. Lewis's That Hideous Strength}

Summary

The aim of the article is to investigate some of the possible sources of inspiration for Orwell's concept of the artificial language called Newspeak, which, in his novel Nineteen Eighty-Four, is shown as an effective tool of enslavement and thought control in the hands of a totalitarian state. The author discusses, in this context, the putative links between Newspeak and really existing artificial languages, first of all Esperanto, and also between Orwell's notion of "doublethink", which is an important feature of the totalitarian mentality, and Czesław Miłosz's notion of "ketman", developed in his book The Captive Mind. But the main emphasis is on the connection between Orwell's book and the slightly earlier novel by C.S. Lewis, That Hideous Strength. It is well known that Orwell knew Lewis's book and expressed his mixed feelings about it. There are many specific, though far from obvious, similarities between the two books, but what seems to have been particularly inspiring for Orwell was Lewis's vision of a thoroughly degenerate language that is used for political manipulation rather than for communication.

Keywords: G. Orwell, C.S. Lewis, totalitarianism, dehumanisation, language degenera$\mathrm{cy}$, artificial language, experimenting with language.

Andrzej Wicher - Prof., professional interests and his publications focus on Medieval and Renaissance studies (including the works of G. Chaucer and W. Shakespeare), and modern fantasy literature (J.R.R. Tolkien and C.S. Lewis in particular), with a special emphasis on the presence of folktale motifs in the works of literature representing various historical periods and literary genres. Until 1997 he worked with the Institute of English Studies of the University of Silesia in Sosnowiec, then he became a member of an analogical Institute at the University of Łódź, where he still works. 